\title{
Psychometric Properties of Graduate Employability Instrument among Malaysian Higher Education Institution Students
}

\author{
Samsilah Roslan ${ }^{1, *}$, Wong Siew Ping ${ }^{1}$, Tajularipin Sulaiman ${ }^{1}$, Habibah Ab Jalil ${ }^{1}$, Siaw Yan-Li ${ }^{2}$ \\ ${ }^{1}$ Faculty of Educational Studies, University Putra Malaysia, Serdang, 43400 Seri Kembangan, Selangor, Malaysia \\ ${ }^{2}$ Faculty of Education, University of Malaya, 50603 Kuala Lumpur, Malaysia
}

Received October 27, 2019; Revised December 2, 2019; Accepted December 24, 2019

Copyright $\subseteq 2020$ by authors, all rights reserved. Authors agree that this article remains permanently open access under the terms of the Creative Commons Attribution License 4.0 International License

\begin{abstract}
Sustainable Development Goals defined that quality education and youth employment are two inter-related indicators that reflect the economic growth. It is important to conduct early assessment of graduate employability to better equip them with necessary knowledge and skills to increase their chance of achieving more sustainable future in their career path. This study aims to develop and validate an instrument termed as the Graduate Employability Instrument to measure the employability attributes among the undergraduate students. This involved five stages of scale development. The technical analyses are done according to the accepted standards in psychometric testing comprising exploratory factor analysis, reliability analysis and confirmatory factor analyses. Total 425 Malaysian undergraduate students were involved in the study. The findings supported the main proposed model with 33 items grouped in 7 constructs; work and career resilience, human and social capital, teamwork, conscientiousness, critical thinking, academic, and leadership. This study contributed in measuring self-perceived employability of undergraduate students, which reflected the dimensions of strengths in the higher education institution studied towards preparing youth to fit in the competitive working environment. This can be used for continuous programmer improvements and intervention plans to improve the quality of education and resolve youth unemployment issues.
\end{abstract}

Keywords Employability, Attributes, Sustainable Development Goal, Graduate, Education

\section{Introduction}

Employability is determined by the assets an individual possesses, in terms of knowledge, skills, attitudes (Hillage \& Polland, 1998; Mason, Williams \& Cranmer, 2006) and commercial understanding (Mason, et al., 2006). These assets, also referred as "work readiness" by Mason et al. (2006), are important for fresh graduates as a determining factor to the success of their carrier paths. Yorke (2006) specified these skills as achievement skills and added that personal attributes as well as understanding will increase graduates' chances of employment and success in the job market.

In the recent increasingly competitive workplace, the perception of guaranteed employment for tertiary degree holders is no longer applicable. Employers currently are more interested in employing graduates who have certain identified employability skills and qualities, in addition to expertise in the respective fields (DEST, 2002). They are searching for candidates who do not possess only basic academic skills, but also higher order thinking skills such as good reasoning, analytical, critical and creative thinking, effective decision making and problem solving. In addition, personal attributes of graduates such as highly responsible, good social skills, cooperative, confidence, independent and self-directed are highly seemed after. However, university students might not be aware of these industry requirements and might not even be able to link their studies or classroom activities to the expectations of the real world. It is here that the universities role must be expanded beyond merely providing teaching and training to increase students' knowledge and expertise in different disciplines, but also preparing students towards becoming highly employable by developing the psychosocial components mentioned. Higher education institutions should strive get to know which dimensions to strengthen in order to best increase the student's employability.

The failure of graduates to be employable may be related to the mismatched emphasis of existing undergraduate programmes (de la Harpe, Radloff \& Wyber, 2000). Graduates are claimed to leave universities without adequate soft skills and knowledge needed for career success (Dass, 2018, August 6; Nik Hairi, Azmi, Rusyda, Arena, \& Khairani, 2012; Singh \& Singh, 2008). Dass (2018) added that the incongruency between the job 
requirements and youth quality is one of the main factors that lead to unemployment. As Mohamad Sattar, Md Yusof, Napsiah, Rashid and Rose Amnah (2009) pointed out from their study, graduates are skilful in their field, but did not have sufficient skills in communication and problem solving, and lack flexibility. Thus, both technical and soft skills trainings are required during tertiary studies to ensure career readiness and career success of undergraduates in the future.

There is a worldwide concern of the effectiveness of higher education institutions in preparing university students with professional skills as well as soft skills to reduce unemployment issue among young population. International Labour Organization (ILO) reported that 5.6\% of the global population were unemployed as of 2017 and remains high, above 192 million in 2018. According to the 17 Sustainable Development Goals (SDGs) proposed by the United Nations (UN), Quality Education (Goal 4) is one of the key Sustainable Development Goal, and this is to ensure inclusive and quality education for all. In line with this, UN targets to substantially increase the number of youths who have relevant skills for employment by 2030 . There is no doubt that education is believed to be the key driver to achieve other Sustainable Development Goals. In addition, Goal 8 that aims to promote inclusive and sustainable economic growth, employment and decent work for all also targets to provide youth with skills that match labour market demand for the purpose of reducing the proportion of youth not in employment.

Therefore, there is a need for Higher Education Institutions (HEIs) to assess employability of the undergraduate students and use this information to strengthen the quality of HEIs. Although some measurements of self-perceived employability have been developed (Bezuidenhout, 2011; Rothwell \& Arnold, 2007), there is still insufficient empirical research in this area, especially in Malaysia context. In addition, most measurements created were more suited for employers but not university students. Hence, the need is to develop a graduate employability measurement that suits both Malaysian industry and HEI contexts.

\subsection{Employability Attributes}

This study focuses on the development of a Graduate Employability Instrument (GEI) to measure undergraduate students' employability. In order to determine the constructs to measure employability, existing theories and models were referred to. The main models reviewed (Figure 1) included Coopers and Lybrand's Employability Dimensions (1998), Fugate, Kinicki and Ashford's Model of Employability (2004), Fugate and Kinicki's Dispositional Model of Employability (2008), Van der Heijde and Van der Heijden's Competence-Based Employability Model (2006), Pool and Sewell's Key to Employability Model (2007), Bridgestock's Conceptual Model of Graduate Attributes for Employability (2009), Mohamed and Hamzah's Graduate Employability Model APEC (2009), and Bezuidenhout's Graduate
Employability Model (2011). Table 1 summarizes the five dominant attributes of employability proposed for this study based on the employability models and theories reviewed.

After a thorough analysis of the models and theories mentioned, five dominant attributes were selected as constructs for the proposed instrument. The five attributes are academic attributes, personal management attributes, exploration attributes, connectivity attributes and career management attributes. Academic attributes refer to the performance of the undergraduate students in the university, which include their knowledge on the discipline of study and relevant co-curricular activities experience. The second attribute of employability, personal management attributes, refer to the way that undergraduate students deal with daily life, such as attitude, sense of responsibility, leadership skills, adaptability and emotional intelligence. The third attribute is the exploration attributes, referring to the way undergraduate students explore the world. The attributes include being imaginative and innovative, and having critical and creative thinking, problem solving and learning skills. The fourth attribute of employability, connectivity attributes, refer to the way undergraduate students interact with people in their surroundings and how they build social network that helps in career development. This domain includes skills in communication, teamwork and technology integration, social capital, and cultural competence. The last attribute of employability, career management attributes, refer to the potential way undergraduate students deal with their career. This domain measures motivation, work and career resilience, career goals, planning and development and learning opportunities exploitation. The instrument was developed and tested for its validity and reliability by referring to the method of scale development proposed by Brown (1983) and Cohen, Swerdlik and Sturman (2013) which involved five stages grouped in three phases.

\begin{tabular}{|l|}
\hline Employability Models and \\
Theories \\
- Employability \\
Dimensions \\
- Model of Employability \\
- Eispositional Model of \\
Employability \\
- Employability Model \\
Eey to Employability \\
- Model \\
Conceptual Model of \\
Graduate Attributes for \\
Employability \\
Graduate Employability \\
Model
\end{tabular}

\begin{tabular}{|l|}
\hline Employability \\
Attributes \\
Graduate \\
Employability \\
Model APEC \\
- Academic \\
attributes \\
Personal \\
management \\
attributes \\
Exploration \\
attributes \\
Connectivity \\
attributes
\end{tabular}

Figure 1. Theoritical Framework 
Table 1. Dominant Employability Attributes proposed in the current study

\begin{tabular}{|c|c|c|c|c|c|}
\hline \multirow[t]{2}{*}{ Employability Models } & \multicolumn{4}{|c|}{ Dominant Employability Attributes } & \multirow[b]{2}{*}{ Career Management } \\
\hline & Academic & Personal management & Exploration & Connectivity & \\
\hline Coopers and Lybrand (1998) & $\begin{array}{c}\text { Knowledge of organization and } \\
\text { how companies in the industry } \\
\text { work }\end{array}$ & & $\begin{array}{l}\text { Traditional intellectual skills } \\
\text { (critical evaluation and logical } \\
\text { thinking); Key skills } \\
\text { (numeracy, information } \\
\text { technology, problem solving } \\
\text { skills, learning ability) }\end{array}$ & $\begin{array}{l}\text { Key skills (communication, } \\
\text { teamwork) }\end{array}$ & \\
\hline $\begin{array}{l}\text { Fugate, Kinicki and Ashford } \\
\qquad(2004)\end{array}$ & $\begin{array}{l}\text { Human capital (expertise, } \\
\text { capabilities, tacit and explicit } \\
\text { knowledge) }\end{array}$ & $\begin{array}{l}\text { Personal adaptability (optimism, } \\
\text { propensity to learn, openness, } \\
\text { internal locus of control, } \\
\text { generalized self-efficacy) }\end{array}$ & & Social capital (support network) & \\
\hline Fugate and Kinicki (2008) & & Openness to changes at work & Work and career proactivity & & $\begin{array}{c}\text { Work and career resilience } \\
\text { (Optimistic, positive self-evaluation } \\
\text { and expectation for future, } \\
\text { confidence); career motivation } \\
\text { (motivation control and learning goal } \\
\text { orientation) } \\
\end{array}$ \\
\hline $\begin{array}{c}\text { Van der Heijde and Van der } \\
\text { Heijden (2006) }\end{array}$ & Occupational expertise & $\begin{array}{l}\text { Anticipation and optimization; } \\
\text { Personal flexibility; Corporate } \\
\text { sense (emotional intelligence) }\end{array}$ & & $\begin{array}{c}\text { Corporate sense (social capital, } \\
\text { social skills) }\end{array}$ & \\
\hline Pool and Sewell (2007) & Degree subject knowledge & Emotional intelligence & $\begin{array}{c}\text { Career development learning } \\
\text { and understanding; Generic } \\
\text { skills }\end{array}$ & & \\
\hline Bridgestock (2009) & Discipline-specific skills & Self-management & $\begin{array}{l}\text { Career building and Generic } \\
\text { skills }\end{array}$ & & \\
\hline Mohamad and Hamzah (2009) & Academic & Personal management & Exploration & Connectivity & \\
\hline Bezuidenhout (2011) & & $\begin{array}{l}\text { Career self-management drive } \\
\text { (emotion management); Personal } \\
\text { dispositions (career resilience, } \\
\text { openness to change, proactivity, } \\
\text { entrepreneurial orientation) }\end{array}$ & $\begin{array}{l}\text { Career self-management drive } \\
\text { (constant gathering of } \\
\text { career-related information }\end{array}$ & $\begin{array}{l}\text { Cultural competence; Personal } \\
\text { dispositions (sociability) }\end{array}$ & $\begin{array}{c}\text { Career self-management drive } \\
\text { (self-evaluation, create career goals } \\
\text { and action plans, exploit } \\
\text { opportunities); Personal dispositions } \\
\text { (Career related core self-evaluations) }\end{array}$ \\
\hline
\end{tabular}




\section{Materials and Methods}

\subsection{Participants and Procedures}

A total of 425 Malaysian undergraduate students from one of the Higher Education Institution (HEI) participated in this study using the final version of the Graduate Employability Instrument (GEI). The HEI was randomly selected from the central region of Malaysia. Only final-year undergraduate students were included in this research. Paper-and-pen self-administered approach was used for data collection. The respondents were given the information sheets that summarized the nature of this study in order to obtain their permission for participating in the study. Only participants who agreed to commit were requested to fill in the survey form. Participation of the subjects was voluntary. All information obtained was meant for research purpose and was kept confidential. Out of the 425 responses, there were $51.5 \%$ $(n=206)$ male and $48.5 \%(n=206)$ female students. In terms of area of study, $50.4 \%(n=214)$ of the participants were from technology and science; while $49.6 \%(n=211)$ were from art and social science.

\subsection{Measures}

The final version of the Graduate Employability Instrument (GEI) included 33 items, developed through a procedure suggested by Brown (1983) and Cohen et al (2013). It measures 7 attributes of employability, namely academic (four items), conscientiousness (five items), leadership (four items), critical thinking (four items), teamwork (four items), human and social capital (five items), and work and career resilience (seven items). Seven-point Likert scale ranging from (1) strongly disagree to (7) strongly agree, were given as response options and used to calculate the test score.

\subsection{Scale Development Procedure}

This study used a quantitative approach as the intention was to develop and validate the Graduate Employability Instrument (GEI) for students in higher education institution. There were three phases of scale development, which involved general procedure in constructing an instrument (Brown, 1983) and five stages to develop a test as suggested by Cohen et al (2013). The flow chart of the processes involved in the scale development is as depicted in Figure 2.

\subsection{Phase 1 of Scale Development}

This phase is comprised of test conceptualisation, construction and try-out.

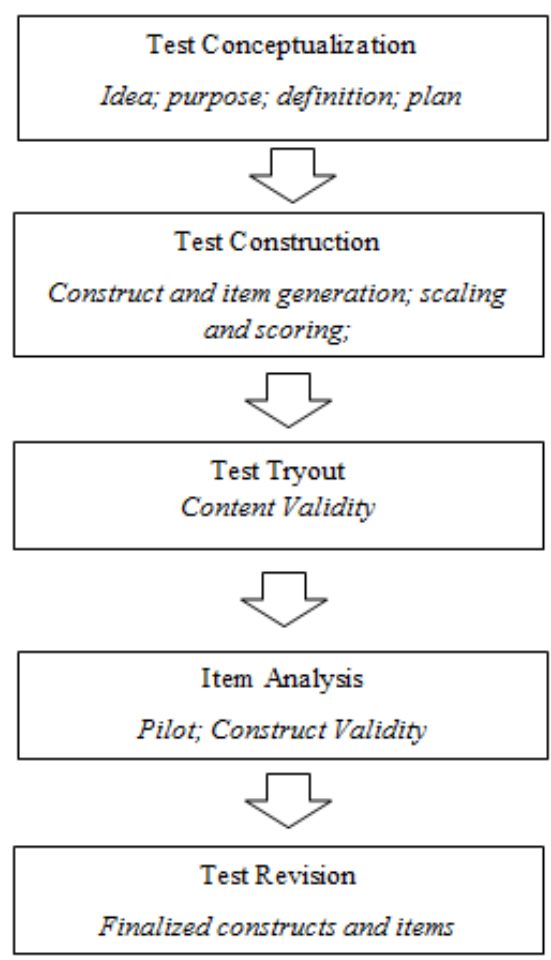

Figure 2. Flow chart of scale development 


\subsubsection{Test Conceptualisation}

In the first stage, test conceptualisation involved forming the idea of a test to understand an existing problem, social phenomenon or focusing to a specific purpose (Cohen et al., 2013). In this study, the instrument is targeted towards finding out the undergraduate students' self-perceived employability in the hope that it will give some indications on the effectiveness of higher education institution in preparing them for the working world. The instrument was developed to provide a more holistic measurement of employability that included various attributes. This is different from most employability tests, which merely assess a particular aspect of employability. The definition of the variable, employability, as well as the constructs, academic attributes, personal management attributes, exploration attributes, connectivity attributes and career management attributes were discussed and defined through the theories and models as indicated in Table 1. In the present study, employability is referred as undergraduate students' perception of attributes that they possess which enable them to obtain employment after they graduate and undergo continuous development in their career.

\subsubsection{Test Construction}

The second stage, test construction, is the process of designing and forming a test (Cohen et al., 2013) by translating into operational terms in the developing instrument plan (Brown, 1983). To describe all the characteristics that can measure the construct, and employability, theories of employability were reviewed. Based on review of literature and the relevant theories and models, this study categorised the characteristics of employability into five domains, namely academic attributes, personal management attributes, exploration attributes, connectivity attributes and career management attributes. These constructs had been defined explicitly. All the behaviours, skills and characteristics that describe these employability dimensions were included in the instrument and supported by the theories and models.
GEI includes nominal, ordinal and ratio scales. Nominal scale was used for respondents' categorical demographic characteristics such as gender; ordinal scale was used for items on employability and ratio scale was used for respondents' continuous demographic attributes such as age and academic performance (Cumulative Grade Point Average, CGPA). A seven-point Likert scale was adopted for all the items that measure the five dimensions of employability: 1 point for strongly disagreeing, 2 points for disagreeing, 3 points for mildly disagreeing, 4 points for neutral, 5 points for mildly agreeing, 6 points for agreeing and 7 points for strongly agreeing to each item. This Likert scale was chosen because research confirmed that the data collected using Likert items becomes significantly more accurate when the number of scale points were between five and seven (Johns, 2010). In addition, Symonds (1924) was the first to suggest that the use of seven-point Likert scale was found to improve the reliability of the scores (Symonds, 1924). Symonds's finding was then supported by Miller (1956) who stated that human mind is capable of distinguishing about a limit of seven different categories when it comes to making judgments about magnitudes of unidimensional stimuli. The scoring model used is the cumulative model where higher test scores indicate higher employability and vice versa. For several decades, some other researches have also proven that seven-point Likert scale maximizes the inter-item consistency and test-retest reliability (Nunnally, 1967; Ramsay, 1973; Oaster, 1989). Preston and Colman (2000) found that five or seven point Likert scale was used in vast majority of rating scales and related psychometric instruments, and seven-point scales were more popular than five-point scales.The questionnaires are divided into two parts. Part A is related to respondents' demographic information including gender, age, course and academic performance. Part B focuses on examining students' employability using GEI. In the final version, the items measure five attributes as indicated in Table 2. 
Table 2. Items and assessment for GEI ( $1^{\text {st }}$ Version $)$

\begin{tabular}{|c|c|c|}
\hline Dimension of Employability & Assess and Measure & Total item \\
\hline Academic attributes & $\begin{array}{l}\text { Academic performance } \\
\text { Job knowledge }\end{array}$ & 6 \\
\hline Personal management attributes & $\begin{array}{c}\text { Attitude } \\
\text { Responsibility } \\
\text { Adaptability } \\
\text { Leadership } \\
\text { Emotional intelligence }\end{array}$ & 33 \\
\hline Exploration attributes & $\begin{array}{c}\text { Imagination } \\
\text { Innovation } \\
\text { Critical and creative thinking } \\
\text { Problem solving skills } \\
\text { Learning skills } \\
\text { Career development learning } \\
\text { Career proactivity }\end{array}$ & 22 \\
\hline Connectivity attributes & $\begin{array}{c}\text { Social capital } \\
\text { Cultural competences } \\
\text { Communication skills } \\
\text { Teamwork } \\
\text { Technology integration skills } \\
\text { Commercial awareness } \\
\end{array}$ & 24 \\
\hline Career management attributes & $\begin{array}{c}\text { Career resilience } \\
\text { Career motivation } \\
\text { Capability career goal } \\
\text { Identify and participate } \\
\text { Exploit opportunities }\end{array}$ & 30 \\
\hline
\end{tabular}

\subsubsection{Test Try-out}

Once the first draft of the instrument was developed, content validity was carried out by three psychology experts from Malaysian HEIs before the instrument was tried out. Both language and structure of the items were checked by the experts to avoid any sensitivity statements and gender bias. In addition, the experts decided the appropriateness of each item in measuring the construct and gave constructive feedback to improve the quality of the instrument. Items were then amended based on the feedback from the professionals. With all the amendments done, there were changes to the proportions of items for each dimension of the GEI. The distribution of items for the second version of GEI is demonstrated in Table 3.

Table 3. Proportion of Items for GEI ( $2^{\text {nd }}$ Version $)$

\begin{tabular}{ccc}
\hline Dimension of Employability & $\begin{array}{c}\text { Item } \\
\text { number }\end{array}$ & Total item \\
\hline Academic attributes & $1-6$ & 6 \\
Personal management attributes & $7-39$ & 33 \\
Exploration attributes & $40-62$ & 23 \\
Connectivity attributes & $63-85$ & 23 \\
Career management attributes & $86-112$ & 27 \\
\hline
\end{tabular}

After the content validity check, $2^{\text {nd }}$ version of GEI was then tried out to further explore its applicability in research settings as well as to ensure the clarity of the instruction on the research instrument and items. For this purpose, a pilot study was done on 231 final-year undergraduate students. The respondents were assured that their information was classified and confidential and the information obtained will only be used for the intended academic purpose.

\subsection{Statistical Analyses}

The analyses described were performed on data derived from the validation study and the final main study. The data in the questionnaires collected was coded for processing using SPSS version 22. The technical analysis of GEI included item reliability and validity. After the data was collected from the test try-out, exploratory factor analysis was done to ensure that all domains represent the constructs that are the respective variables. The internal consistency reliability of the instrument was measured to ensure that homogeneity of the test. This was done by referring to the Cronbach's Alpha coefficient of each construct. Both the exploratory factor analysis and reliability analysis were run with SPSS version 22. Confirmatory factor analysis was then carried out using AMOS to confirm that the proposed model adheres to the standard goodness of fit indices.

\section{Finding and Discussion}

The finding and discussion reported in this section refer to the results from Phase 2 and Phase 3 of the scale development. In Phase 2, validation study involved 231 final year undergraduate students for the item analysis, internal consistency reliability and construct validity. To enhance final version of the instrument, the results of the revised test were reported in Phase 3 of the scale development which involved 425 final year undergraduate students 


\subsection{Phase 2 of Scale Development: Enhancement}

A pilot study was done on 231 final year undergraduate students from one of the higher educational institution in Malaysia. They were all final year students with mean age of 22.28 years $(\mathrm{SD}=1.52)$ and mean CGPA of 3.2

$(\mathrm{SD}=.41)$. Normality test was conducted and showed that the data was normally distributed with the skewness value of .243. According to Leech and her colleagues (2011), the data is considered at least approximately normal with skewness value of -1 to 1 . For the 231 sets of response, technical validity analysis was done, followed by reliability analysis.

\subsubsection{Item Analysis}

Item analysis is important to measure the quality of each item in a test and the test as a whole. Exploratory factor analysis was conducted to determine whether the suggested construct and the large item pool measure employability. There are a total of 5 constructs with 112 items generated in the $2^{\text {nd }}$ version of the GEI through first phase of the scale development. To consider what items to remove or retain, the communality values and factor loadings of each item was computed. Every item should have at least a standardised loading estimate or communality value of .5, and ideally .7 or higher (Hair et al., 2006). In addition, Costello and Osborne (2005) commented that a good factor consists of at least five items with strong loading (greater than .50) and factors with less than three items are considered weak. Since there were a lot of items therefore factor analysis for this study was set at .5. Factors with less than three items of strong loading were removed by having the item with communality value of less than .5 or the least factor loading deleted one by one. Every deletion of an item was followed by a rerun of factor analysis. The generation of factor analysis stopped when all factors have at least three items with significantly strong loadings. The suitability of the data for factor analysis was proven in Table 4, which describes the extraction of seven common factors for 33 items. The result indicated that the 231 students were adequate to conduct a factor analysis for GEI. There were no cross loadings. Seven factors were extracted with eigenvalues of greater than one. These seven factors account for much of the variation among the items $(68.48 \%)$. Kaiser-Meyer-Olkin (KMO) index increased to .929 and the Bartlett's test of sphericity was significant $(p<.001)$. According to Tabachnick and Fidell (2013), the Bartlett's test of sphericity is significant since the $p$ value is less than .05 and KMO index of greater than .6 and indicates the appropriateness to run factor analysis on the data. In addition, all items showed communalities of greater than .6. According to MacCallum and his colleagues (1999), this is a high level of communality, in other words, this indicated that the sample size was adequate to measure employability with the remaining 33 items.

Table 4. Results for the extraction of common factors

\begin{tabular}{cccc}
\hline Factor & Eigenvalue & $\begin{array}{c}\text { Percentage of } \\
\text { variance }\end{array}$ & $\begin{array}{c}\text { Cumulative } \\
\text { percentage }\end{array}$ \\
\hline 1 & 13.375 & 40.530 & 40.530 \\
2 & 2.214 & 6.710 & 47.240 \\
3 & 2.037 & 6.174 & 53.413 \\
5 & 1.575 & 4.773 & 58.186 \\
6 & 1.196 & 3.623 & 61.809 \\
7 & 1.130 & 3.425 & 65.234 \\
& 1.071 & 3.244 & 68.478 \\
\hline
\end{tabular}

A total of 79 items from the original 112 items $\left(2^{\text {nd }}\right.$ version of GEI) with communality value of less than .5 or weaker factor loadings were deleted. Table 5 indicates the factor loading for GEI with acceptance of 33 items within seven factors. Based on the items extracted, most factors were renamed instead of using the proposed label. As shown in

Table 5, the five attributes were renamed to seven factors namely, work and career resilience (seven items); human and social capital (five items); teamwork (four items); conscientiousness (five items); critical thinking (four items); academic (four items); leadership (four items). 
Table 5. Factor loading of items retained in GEI ( $3^{\text {rd }}$ Version)

\begin{tabular}{|c|c|c|}
\hline Factor & Item & Factor loading \\
\hline \multirow{7}{*}{$\begin{array}{c}\text { Work and Career } \\
\text { Resilience }\end{array}$} & 89. I do not give up easily in pursuing my goals. & .754 \\
\hline & 88. I take problems as challenges. & .744 \\
\hline & 111. I accept challenge because I know I will learn from it. & .741 \\
\hline & 108. I am always self-motivated. & .672 \\
\hline & 110. I always evaluate and monitor my own performance. & .659 \\
\hline & 95. I regularly evaluate myself. & .606 \\
\hline & 87. I work hard until I achieve my goals. & .586 \\
\hline \multirow{7}{*}{$\begin{array}{l}\text { Human and social } \\
\text { capital }\end{array}$} & 77. I can predict the future trends of my field of study. & .722 \\
\hline & 76. I have studied the history about my field of study. & .702 \\
\hline & 78. When I need to plan my future career, I know who to & .675 \\
\hline & consult. & .649 \\
\hline & 81. I know how to use social network to support career & .537 \\
\hline & building. & \\
\hline & 72. I always keep myself updated of the latest technology & \\
\hline \multirow[t]{4}{*}{ Teamwork } & 68. I can work in a team to achieve a goal. & .809 \\
\hline & 69. I know how to contribute in a team. & .745 \\
\hline & 67. I have learnt how to work in a team. & .737 \\
\hline & 66. I can talk and listen to the others. & .518 \\
\hline \multirow[t]{5}{*}{ Conscientiousness } & 9. I normally complete my tasks on time. & .846 \\
\hline & 8. I am always punctual. & .761 \\
\hline & 12. I carry my responsibilities well. & .656 \\
\hline & 55. I always complete my assignments given by the lecturers. & .614 \\
\hline & 33. I manage my time wisely. & .594 \\
\hline \multirow[t]{4}{*}{ Critical Thinking } & 47. I always evaluate the credibility of sources of information. & .800 \\
\hline & 48. I can differentiate between facts and assumptions. & .759 \\
\hline & 49. I can define a problem and identify the contributing factors. & .684 \\
\hline & 46. I can interpret information accurately. & .629 \\
\hline \multirow[t]{4}{*}{ Academic } & 2. I know a lot of skills about the field I am studying. & .765 \\
\hline & 3. I know how to apply the skills I learnt in real life situations. & .753 \\
\hline & 1. I have a lot of knowledge about the field I am studying. & .723 \\
\hline & 4. I know the job scope of all the positions in my field. & .605 \\
\hline \multirow[t]{4}{*}{ Leadership } & 14. I normally volunteer myself as a leader in a group work. & .827 \\
\hline & 17. I am good in persuading my group members to agree to me. & .602 \\
\hline & 13. I have learnt about various leadership skills. & .571 \\
\hline & 15. When I am in a group, I am able to set a practical goal. & .558 \\
\hline
\end{tabular}

\section{A. Factor 1: Work and career resilience}

Items $88,87,89,95,108$ and 111 were loaded on the first factor. All these items were proposed to measure career management related to work and career resilience. According to Fugate and Kinicki (2008), work and career resilience included having optimistic attitude, proactive self-regulation such as self-monitoring and self-evaluating, positive expectation for future and confidence in dealing with objective and affective challenges. Hence the factor was named "work and career resilience".

\section{B. Factor 2: Human and social capital}

The second factor consisted of items 72, 76, 77, 78 and 81 . These items were proposed to measure connectivity. Items 72, 76, and 77 were specifically about disciplinary knowledge while item 78 and 81 were related to social capital. These items could be related to one of the dimensions in Fugate, Kinicki and Ashford's (2004) Model of Employability called human and social capital. Human capital refers to the personal variables that influence an individual's career advancement such as knowledge while social capital refers to the social support network. So the factor was labelled "human and social capital".

\section{Factor 3: Teamwork}

Items 66, 67, 68 and 69 were salient with the third factor. All the items were also proposed to measure connectivity or more specifically, the teamwork. Teamwork was one of the key skills in Coopers and Lybrand's (1998) Employability Dimensions. Besides, the Ministry of Higher Education (2012) supported Mohamad and Hamzah (2009)'s Graduate Employability Model APEC where teamwork was one of the elements under the connectivity construct. Thus, the third factor was called "teamwork".

\section{Factor 4: Conscientiousness}

Items 8, 9, 12 and 33 were proposed to assess personal management and item 55 proposed in exploratory attribute 
were loaded on the fourth factor. All these items were related to conscientiousness, a trait in the Big-Five trait theory. Conscientiousness is related to the tendency to follow norms and rules, make and follow plans, delay gratification and be goal-oriented (Roberts, Jackson, Fayard Edmonds and Meints, 2009). Conscientious individuals are self-disciplined, task-focused and organized. Hence the fourth factor was named "conscientiousness".

\section{E. Factor 5: Critical Thinking}

The fifth factor consisted of items 46, 47, 48 and 49. These items examined critical thinking skills as one of the important attributes established under the employability scale. For example, Coopers and Lybrand (1998) included critical evaluation in their Employability Dimensions under traditional intellectual skills. Mohamad and Hamzah (2009)'s Graduate Employability Model APEC also included critical thinking under the exploration construct. And the Ministry of Higher Education Malaysia (2012) has accepted the model as core skills to develop among Malaysian learners. According to Facione (2015, p. 25), "critical thinking is sceptical without being cynical. It is open-minded without being wishy-washy. It is analytical without being nit-picky. Critical thinking can be decisive without being stubborn, evaluative without being judgmental, and forceful without being opinionated". Characteristics of a critical thinker include systematic, inquisitive, judicious, truth-seeking, analytical, open-minded and confident in reasoning.

\section{F. Factor 6: Academic}

Items 1, 2, 3 and 4 were developed to measure the academic attribute focusing on students' knowledge and skills on discipline of study. Mohamed and Hamzah (2009) suggested that it is important for students to be exposed to their disciplinary and possess adequate knowledge about real world working environment.

\section{G. Factor 7: Leadership}

The last factor included items 13, 14, 15 and 17, which were developed to measure leadership skills. Leadership skills were included under the personal management attribute in Mohamad and Hamzah (2009)'s Graduate Employability Model APEC. Leadership is also one of the six attributes in the latest Malaysia Education Blueprint 2015-2025 (Higher Education) (Ministry of Higher Education, 2015). The Ministry of Higher Education expects higher education to educate learners to communicate effectively, to be intelligent emotionally, responsible socially, competitive, resilient, confident, and able to work across cultures. The items were related to some of these elements. Thus, the factor was named "leadership".

\subsubsection{Internal Consistency Reliability}

Internal consistency of items of GEI (third version) was assessed using Cronbach's alpha. The Cronbach's alpha computed was .952 with 33 items which is acceptable according to Pallant (2001). Based on Fisher's (2007) rating, the instrument's reliability level is excellent. Comparing the reliability of each factor in GEI with Fisher's rating, leadership dimension is fairly reliable ( $\alpha=.796$ ) while all the other dimensions have good reliability $(.80<\alpha<.90)$ Table 6 shows the Cronbach's alpha for each factor in GEI after amendment.

Table 6. Cronbach's Alpha for Factors of GEI (Third Version)

\begin{tabular}{cc}
\hline Factor & Cronbach's Alpha \\
\hline Work and career resilience & .903 \\
Human and social capital & .864 \\
Teamwork & .866 \\
Personal management & .837 \\
Critical Thinking & .862 \\
Academic & .837 \\
Leadership & .796 \\
Overall & $\mathbf{. 9 5 2}$
\end{tabular}

\subsubsection{Construct Validity}

To ensure that the constructs were valid in measuring employability, confirmatory factor analysis (CFA) was conducted on the 33 remaining items. This is to assess the goodness-of-fit of the model. Hair et al. (2006) stated that reporting at least one incremental index and one absolute index in addition to the chi-square $\left(\chi^{2}\right)$ value and the associated degrees of freedom $(d f)$ would be sufficient to evaluate the model. Moreover, there should be at least one badness-of-fit index reported. With that, Hair et al. (2006) recommended reporting $\chi^{2}$ value, $d f$, the CFI and the RMSEA.

The goodness-of-fit indices for the model were as follows: $\chi^{2}=894.026(p<.000), d f=474, \mathrm{CFI}=.906$, and $\mathrm{RMSEA}=.062$. According to Hair et al. (2006), $\chi^{2}$ value with significant $p$ value of less than .05 shows good model fit. They also associated CFI above .90 and RMSEA below .10 with good model fit. All these goodness-of-fit indices showed that this model of Employability was fit. Construct validity refers to the test of the hypothesized constructs that represent the concept the researcher is measuring. To assess construct validity of GEI, convergent validity was conducted, which referred to the values of standardized factor loadings, construct reliability (CR) and average variance extracted (AVE). Table 7 shows the standardized factor loadings, CR and AVE of $3^{\text {rd }}$ version of GEI from CFA. 
Table 7. Factor loadings, Construct Reliability (CR) and Average Variance Extracted (AVE) of GEI (Version 3)

\begin{tabular}{|c|c|c|c|c|}
\hline Factor & Item & $\begin{array}{c}\text { Factor } \\
\text { Loadings }\end{array}$ & $(\mathrm{CR})$ & $(\mathrm{AVE})$ \\
\hline Academic & $\begin{array}{l}1 . \\
2 . \\
3 . \\
4 .\end{array}$ & $\begin{array}{l}.815 \\
.813 \\
.648 \\
.733\end{array}$ & .841 & .571 \\
\hline $\begin{array}{c}\text { Personal } \\
\text { management }\end{array}$ & $\begin{array}{c}8 . \\
9 . \\
12 . \\
33 . \\
55\end{array}$ & $\begin{array}{l}.816 \\
.651 \\
.748 \\
.710 \\
.677\end{array}$ & .845 & .522 \\
\hline Leadership & $\begin{array}{c}13 . \\
14 . \\
15 . \\
17 .\end{array}$ & $\begin{array}{l}.728 \\
.672 \\
.752 \\
.680\end{array}$ & .801 & .502 \\
\hline $\begin{array}{l}\text { Critical } \\
\text { Thinking }\end{array}$ & $\begin{array}{l}46 . \\
47 \\
48 \\
49\end{array}$ & $\begin{array}{l}.765 \\
.809 \\
.759 \\
.800\end{array}$ & .864 & .614 \\
\hline Teamwork & $\begin{array}{l}66 . \\
67 . \\
68 . \\
69 .\end{array}$ & $\begin{array}{l}.714 \\
.820 \\
.881 \\
.767\end{array}$ & .874 & .637 \\
\hline $\begin{array}{l}\text { Human and } \\
\text { social capital }\end{array}$ & $\begin{array}{c}72 . \\
76 . \\
77 . \\
78 . \\
81\end{array}$ & $\begin{array}{l}.747 \\
.761 \\
.827 \\
.737 \\
.686\end{array}$ & .867 & .567 \\
\hline $\begin{array}{l}\text { Work and } \\
\text { career } \\
\text { resilience }\end{array}$ & $\begin{array}{c}87 . \\
88 . \\
89 . \\
95 . \\
108 . \\
110 . \\
111 .\end{array}$ & $\begin{array}{l}.797 \\
.840 \\
.802 \\
.657 \\
.696 \\
.757 \\
.746\end{array}$ & .904 & .576 \\
\hline
\end{tabular}

Based on Hair et al. (2006), every item should have at least a factor loading of .5, and ideally .7 or higher to show good convergent validity. CFA again proved that all items demonstrated strong factor loading in the model. As shown in Table 4.9, all items had factor loadings in the range of .64 and .89. Further, that all construct have CR value in the range of .80 and .91 . This fulfilled the suggestion by Hair et al. (2006) that CR value should be 7 or greater to indicate adequate convergence. The last indicator of convergent validity was AVE value at least .5 or higher as evidence to prove adequate convergent validity (Hair et al., 2006). Referring to Table 4.9, AVE of all seven constructs were in the range of .50 and .64. Hence, convergent validity of GEI was proven with all three conditions fulfilled. To measure discriminant validity, Hair et al. (2006) suggested that the square of the correlation between two factors should be less than AVE estimates for two factors. Table 8 shows the square of the correlation among the constructs and AVE for each construct. The divergent validity of GEI was proven by having all AVEs of each construct greater than any of the square of the correlation between two factors. Further, Table 8 also provides additional evidence of divergent validity as it shows that there is no cross-loading for all items in GEI. Hair et al. claimed that each item of a test should measure only one latent construct to add distinctiveness between constructs.

Table 8. Square of Correlation and Average Variance Extracted (AVE) of GEI (Third Version)

\begin{tabular}{|c|c|c|c|c|c|c|c|}
\hline $\begin{array}{c}\text { Construc } \\
\mathrm{t}\end{array}$ & 1 & 2 & 3 & 4 & 5 & 6 & 7 \\
\hline 1 & $\begin{array}{c}(.571 \\
)\end{array}$ & .255 & .318 & .294 & .209 & .557 & .316 \\
\hline 2 & & $\begin{array}{c}(.522 \\
)\end{array}$ & .388 & .184 & .270 & .296 & .403 \\
\hline 3 & & & $\begin{array}{c}(.502 \\
)\end{array}$ & .441 & .389 & .371 & .477 \\
\hline 4 & & & & $\begin{array}{c}(.614 \\
)\end{array}$ & .389 & .514 & .417 \\
\hline 5 & & & & & $\begin{array}{c}(.637 \\
)\end{array}$ & .396 & .531 \\
\hline 6 & & & & & & $\begin{array}{c}(.567 \\
)\end{array}$ & .480 \\
\hline 7 & & & & & & & $\begin{array}{c}(.576 \\
)\end{array}$ \\
\hline
\end{tabular}

1=academic; $2=$ personal management; $3=$ leadership; $4=$ critical thinking; $5=$ teamwork; $6=$ human and social capital; 7 - work and career resilience

\subsection{Phase 3 of Scale Development: Confirmation}

This session reports the last phase of scale development by used the $3^{\text {rd }}$ Version of GEI amended thru the item analysis. The purpose of test revision in phase 3 was to enhance the quality of the measurement by revising the test of confirmatory and reliability analyses. Subsequently, we confirmed the validation and reliability of the instrument for further study. Amended GEI ( $3^{\text {rd }}$ version) was tried out on 425 final-year undergraduate students from the HEI in the centre region of Peninsular Malaysia. The data was normally distributed is the skewness value of .005 . As discussed earlier, the data was at least approximately normal with skewedness value of -1 to 1 (Leech et al., 2011). For this main study, confirmatory factor analysis was run, and followed by reliability analysis.

\subsubsection{Confirmatory Factor Analysis}

Confirmatory factor analysis was carried out to reassure that the seven factors of 33 items are appropriate to measure employability. As discussed earlier, reporting $\chi^{2}$ value, $d f$, the CFI and the RMSEA would be enough to evaluate the model. The goodness-of-fit indices for the model were as follows: $\chi 2=1296.17(\mathrm{p}<.000), \mathrm{df}=474$, $\mathrm{CFI}=.919$, and RMSEA $=.063$. According to Hair et al. (2006), $\chi 2$ value with significant $p$ value of less than .05 , CFI above .90 and RMSEA below .10 indicated good model fit. Hence, it could be concluded that the model of Employability is fit. Figure 3 shows the confirmatory factor analysis model for GEI. 


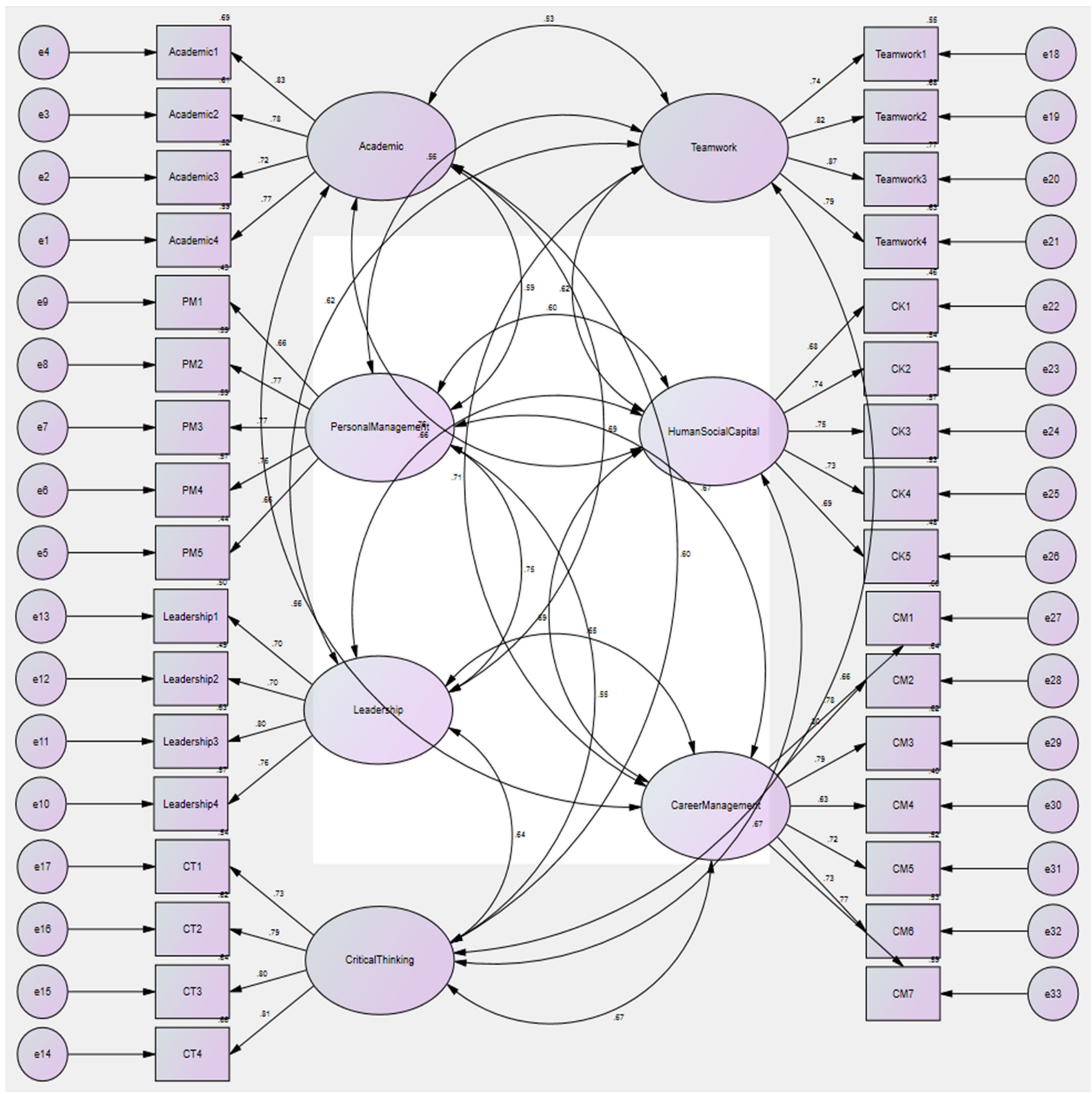

Figure 3. Confirmatory Factor Analysis for GEI (Third Version, Main Study

To assess construct validity of GEI, both convergent and discriminant validity were conducted. For convergent validity, we referred to the values of standardized factor loadings, construct reliability (CR) and average variance extracted (AVE). Table 9 shows the standardized factor loadings, CR and AVE of amended GEI from CFA. Based on the results, all items in GEI showed ideal factor loadings were greater than .7 as suggested by Hair et al. (2006), except for item 5 . These 32 items have factor loadings in the range of .7 and .9. Although factor loading for item 5 valued at .675 was not ideal but it still met the good rule of thumb of greater than .5 as recommended by Hair et. al (2006). The second evidence of convergent validity was that all constructs have CR value of .7 or greater (Hair et al., 2006). Referring to Table 9, the CR value of all the factors were in the range of .75 and .85 . The last proof of convergent validity was AVE should be .5 or higher to indicate adequate convergence. Again, findings showed that AVE of all seven constructs was in the range of .55 and .72. Hence, convergent validity of GEI was proven with all three evidences provided. 
Table 9. Factor Loadings, Construct Reliability (CR) and Average Variance Extracted (AVE) of GEI (Third Version, Main Study)

\begin{tabular}{|c|c|c|c|c|}
\hline Factor & Item & Factor Loading & $\mathrm{CR}$ & AVE \\
\hline \multirow[t]{4}{*}{ Academic } & 1. & .853 & .763 & .652 \\
\hline & 2. & .805 & & \\
\hline & 3. & .769 & & \\
\hline & 4. & .801 & & \\
\hline \multirow[t]{5}{*}{ Personal management } & 5. & .675 & .791 & .575 \\
\hline & 6. & .798 & & \\
\hline & 7. & .816 & & \\
\hline & 8. & .764 & & \\
\hline & 9. & .729 & & \\
\hline \multirow[t]{4}{*}{ Leadership } & 10. & .758 & .754 & .587 \\
\hline & 11. & .702 & & \\
\hline & 12 & .818 & & \\
\hline & 13. & .782 & & \\
\hline \multirow{4}{*}{ Critical Thinking } & 14. & .763 & .765 & .662 \\
\hline & 15. & .817 & & \\
\hline & 16. & .831 & & \\
\hline & 17. & .842 & & \\
\hline \multirow[t]{4}{*}{ Teamwork } & 18. & .797 & .771 & .714 \\
\hline & 19. & .858 & & \\
\hline & 20. & .892 & & \\
\hline & 21 & .829 & & \\
\hline \multirow[t]{5}{*}{ Human and social capital } & 22. & .715 & .788 & .551 \\
\hline & 23. & .757 & & \\
\hline & 24. & .777 & & \\
\hline & 25. & .740 & & \\
\hline & 26. & .719 & & \\
\hline \multirow[t]{7}{*}{ Work and career resilience } & 27. & .815 & .846 & .619 \\
\hline & 28. & .828 & & \\
\hline & 29. & .819 & & \\
\hline & 30. & .702 & & \\
\hline & 31. & .754 & & \\
\hline & 32. & .773 & & \\
\hline & 33. & .809 & & \\
\hline
\end{tabular}

Besides convergent validity, discriminant validity was also important for construct validity. To prove discriminant validity of a test, Hair et al. (2006) recommended to compare the square of the correlation between two factors and AVE estimates for two factors. It was suggested that AVE estimates for two factors should be greater than the square of the correlation between two factors. The results showed that none of the square of the correlation between two factors was greater than the AVE estimates for two factors. Thus, discriminant validity for GEI was proven. Table 10 shows the square of the correlation among the constructs and AVE for each construct.

Table 10. Square of Correlation and Average Variance Extracted (AVE) of GEI (Third Version, Main Study)

\begin{tabular}{cccccccc}
\hline Construct & 1 & 2 & 3 & 4 & 5 & 6 & 7 \\
\hline 1 & $(.652)$ & .450 & .560 & .462 & .393 & .540 & .421 \\
2 & & $(.575)$ & .538 & .413 & .445 & .445 & .558 \\
3 & & & $(.587)$ & .507 & .483 & .510 & .520 \\
4 & & & $(.662)$ & .542 & .527 & .549 \\
5 & & & & $(.714)$ & .471 & .605 \\
6 & & & & & $(.551)$ & .549 \\
7 & & & & & & \\
\hline
\end{tabular}

1=academic; 2=personal management; 3=leadership; 4=critical thinking; 5=teamwork; $6=$ human and social capital; 7- work and career resilience 


\subsubsection{Reliability}

Reliability test was conducted and Cronbach's Alpha $(\alpha)$ of GEI is .954. The value showed that the instrument was reliable according to Pallant (2001) recommendation of greater than .70 , and the reliability level of the test was excellent based on Fisher's (2007) rating. Comparing the Cronbach's Alpha value of all the seven factors of employability to Fisher's (2007) rating, all the constructs have good level of reliability $(.80<\alpha<.90)$. Table 11 shows the Cronbach's Alpha of each factor of GEI.

Table 11. Cronbach's Alpha of Each Factor of GEI (Third Version, Main Study)

\begin{tabular}{cc}
\hline Factor & Cronbach's Alpha $(\alpha)$ \\
\hline Work and career resilience & .897 \\
\hline Human and social capital & .840 \\
\hline Teamwork & .881 \\
\hline Personal management & .840 \\
\hline Critical Thinking & .863 \\
\hline Academic & .857 \\
\hline Leadership & .823 \\
\hline Overall & .954 \\
\hline
\end{tabular}

\section{Conclusions and Recommendation}

In this study, an instrument was developed to measure the employability of undergraduate students who are going to join the workforce soon. They are expected to be equipped with sufficient knowledge and skills to face the real-life working environment. With this instrument, employability of final-year undergraduate students from the individual or the students' perspective can be analysed. The analysis can be compared with the demand of the labour market and industries to find out whether the supply from tertiary education matches the demand. The ministry or the institutions of tertiary education can then use this information to improve or decide the education direction and blueprints. For this study, employability was defined as undergraduate students' perception of attributes that they possess which enable them to obtain employment after they graduate and undergo continuous development in their career. Employability was explored from individual perspective, more specifically, undergraduate students' perspective of their own employability.

The procedure of developing the GEI was sequentially followed according to Brown (1983) and Cohen et al. (2013). In the pilot study, exploratory factor analysis was conducted to determine whether the proposed constructs and the large items pool in GEI (second version) measure employability. There were three steps to follow sequentially in exploratory factor analysis. With that, $3^{\text {rd }}$ version of GEI proposed which consisted of 33 items grouped in seven constructs, namely work and career resilience, human and social capital, teamwork, conscientiousness, critical thinking academic, and leadership. For the main study, data was analysed through confirmatory factor analysis. Goodness-of-fit indices again showed that the proposed model for employability had a good model fit. Evidence in the result confirmed the validity and reliability of the final version of GEI $\left(3^{\text {rd }}\right.$ version). Since the instrument had been developed and validated following psychometric test construction, the researcher believes that GEI could be used to measure self-perceived employability of final-year undergraduate students. The data could be useful for higher education institutes to assess the quality of these soon-to-be graduates.

This study has produced a sound instrument to measure employability of undergraduate students. The educators and the management of the universities can use this test to measure their undergraduate students' employability skills, thus predict their readiness or success for a job employment after they graduated. The results could reflect the effectiveness of higher education institutions in preparing undergraduate students with expertise as well as employability skills to fit in competitive working environment. The domain with lower score would indicate the weakness of most students. HEIs could use this finding to plan some interventions to improve the employability of undergraduate students. This is vital to produce graduates that fulfil the job market demands and resolve the unemployment issue among graduates especially in Malaysia. Besides, undergraduate students, whether in their final year or not, could use this instrument to assess their employability. This enables them to identify their strengths and weaknesses so that they could put in more effort to deal with their weaknesses before they graduate. University is a place for students to explore and develop their potential and learn from their mistakes. As compared to workplace, employers may have less tolerance towards mistakes as employers expect employees to solve but not create problems.

In this study, GEI was developed and validated to measure self-perceived employability of final-year undergraduate students. Results showed that it has ideal factor loadings to prove its validity and good internal consistency reliability. However, replication of GEI is recommended for future research with larger sample size and different populations as any given sample would never reflect its population perfectly. Replication of the factor analysis procedures would demonstrate that the constructs result in this research were not peculiar to this sample population. Moreover, this research discussed employability from the individual perspective. Economic-social and organizational perspectives of employability were excluded. Future researchers are suggested to include either of the perspective excluded in this study or both perspectives. Input from the industries or experts would further determine the effectiveness of higher 
education in producing employable graduates. Students may also use the test to find out whether they have the quality required in workplace environment and put some effort into self-enhancement before they graduate.

\section{REFERENCES}

[1] Bezuidenhout, M. (2011). The development and evaluation of a measure of graduate employability in the context of the new world of work, from MCom dissertation, University of Pretoria, Pretoria. Retrieved 11th March, 2014 from http://upetd.up.ac.za/thesis/available/etd-10082011-133535

[2] Bridgestock, R. (2009). The graduate attributes we've overlooked: Enhancing graduate employability through career management skills. Higher Education Research \& Development, 28(1), 31-44.

[3] Brown, F.G. (1983). Principles of education and psychological testing. New York: Holt, Rinehart \& Winston.

[4] Cohen, R.J., Swerdlik, M.E. \& Sturman, E.D. (2013). Psychological testing and assessment: An introduction to tests and measurement (8th ed.). New York: McGraw-Hill.

[5] [5] Coopers \& Lybrand. (1998). Skills development in higher education. Report for CVCP/DfEE/HEQE, November, London: Committee of Vice-Chancellors and Principals of the universities of the UK (CVCP).

[6] Costello, A.B., \& Osborne, J.W. (2005). Best practices in exploratory factor analysis: Four recommendations forgetting the most from your analysis. Practical Assessment, Research and Evaluation, 10(7), 1-9.

[7] de la Harpe, B., Radloff, A., \& Wyber, J. (2000). Quality and generic (professional) skills. Quality in Higher Education, 6(3), 231-243.

[8] [8] Dass, A. (2018, August 6). Young and jobless in Malaysia. The Star. Retrieved 11 January 2019 from https://www.thestar.com.my/business/business-news/2018/ 08/06/young-and-jobless-in-malaysia/.

[9] DEST. (2002). Employability skills for the future, a report by the Australian Chamber of Commerce and Industry and the Business Council of Australia for the Department of Education, Science and Training, Canberra.

[10] Facione, P.A. (2015). Critical thinking: What it is and why it counts. Hermosa Beach, CA: Measured Reasons LLC.

[11] Fisher, W.P. Jr. (2007). Rasch Measurement Transaction. Transaction of the Rasch Measurement SIG American Education Research Association, 21(1), p.1095.

[12] Fugate, M. \& Kinicki, A.J. (2008). A dispositional approach to employability: Development of a measure and test of implications for employee reactions to organizational change. Journal of Occupational and Organizational Psychology, 81, 503-527.

[13] Fugate, M., Kinicki, A.J., \& Ashford, B.E. (2004) Employability: A psycho-social construct, its dimensions applications. Journal of Vocational Behavior, 65, 14-38.
[14] Hair, J.F., Black, W.C., Babin, B.J., Anderson, R.E., \& Tatham, R.L. (2006). Multivariate Data Analysis. New Jersey: Pearson Education, Inc.

[15] Hillage, J., \& Polland, E. (1998). Employability: Developing a framework for policy analysis. United Kingdom: Research Brief 85, Department for Education and Employment.

[16] Johns, R. (2010). Likert items and scales. Survey Question Bank: Methods Fact Sheet 1 (March 2010). Retrieved from https://www.sheffield.ac.uk/polopoly_fs/1.597637!/file/lik ertfactsheet.pdf.

[17] Leech, N.L., Barrett, K.C., \& Morgan, G.A. (2011). IBM SPSS for intermediate statistics: Use and interpretation (4th ed.). New York: Routledge Academic.

[18] MacCallum, R.C., Widaman, K.F., Zhang, S., \& Hong, S. (1999). Sample size in factor analysis. Psychometric Methods, 14(1), 84-99.

[19] Mason, G.W., Williams, G., \& Cranmer, S. (2006) Employability skills initiatives in higher education: What effects do they have on graduate labour outcomes? Retrieved 12 July 2013 from https://niesr.ac.uk/sites/default/files/publications/061006_9 1251.pdf.

[20] Miller, G.A. (1956). The magical number seven, plus or minus two: Some limits on our capacity for processing information. Psychological Review, 63(2), 81-97.

[21] Ministry of Higher Education. (2012). The National Graduate Employability Blueprint 2012-2017. Selangor: University Putra Malaysia Press.

[22] Ministry of Higher Education. (2015). Malaysia Education Blueprint 2015-2025 (Higher Education). Putrajaya, Malaysia: Kementerian Pendidikan Malaysia.

[23] Mohamad Sattar, R. MdYusof, I., Napsiah, I, Rashid R., \& Rose Amnah, A. R. (2009). Aspek kemahiran 'employability' yang dikehendaki majikan industry pembuatan masa kini. Jurnal Pendidikan Malaysia, 34(2), 67-69.

[24] Mohamed, H., \& Hamzah, M.S.G. (2009). Employability profiles of graduates: The Malaysian scenario of an employer perspective. The 5th QS-Apple Conference, Kuala Lumpur. Retrieved 12 June 2013 from http://www.qsapple.org/GEM5b_Hapidah.pdf.

[25] Nik Hairi, O., Azmi, A.M., Rusyda, H.M., Arena, C.K., \& Khairani, A.A. (2012). Graduates' employability skills based on current job demand through electronic advertisement. Asian Social Science, 8(9), 103-110.

[26] Nunnally, J.C. (1967). Psychometric theory. New York: McGraw-Hill.

[27] Oaster, T.R.F. (1989). Number of alternatives per choice point and stability of Likert-type scales. Perceptual and Motor Skills, 68, 549-550.

[28] Pallant, J. (2001). SPSS Survival Manual. A step-by-step Guide to Data Analysis Using SPSS for Windows. New South Wales, Australia: Allen \& Unwin.

[29] Pool, L.D., \& Sewell, P. (2007). The key to employability: Developing a practical model of graduate employability. Education + Training, 49(4), 277- 289.

[30] Preston, C.C. \& Colman, A.M. (2000). Optimal number of 
response categories in rating scales: Reliability validity, discriminating power, and respondent preferences. Acta Psychologia, 104, 1-15.

[31] Ramsay, J.O. (1973). The effect of number of categories in rating scales on precision of estimation of scale values. Psychometrical, 38, 513-533.

[32] Rothwell, A., \& Arnold, J. (2007). Self-perceived employability: Development and validation of a scale. Personnel Review, 46(1), 23-41.

[33] Singh, G.K.G., \& Singh, S.K.G. (2008). Malaysian graduates' employability skills. UniTAR e-Journal, 4(1), $15-45$.

[34] Symonds, P.M. (1924). On the loss of reliability in ratings due to coarseness of the scale. Journal of Experimental Psychology, 7, 456-461.

[35] Tabachnick, B.G., \& Fidell, L.S. (2013). Using multivariate statistics (6th ed.). Boston, MA: Pearson.

[36] Van der Heijde, C.M., \& Van der Heijden, B.I.J.M. (2006). A competence-based and multi-dimensional operationalization and measurement of employability. Human Resource Management, 45, 449-476.

[37] Yorke, M. (2006). Employability in higher education: What it is - what it is not. Learning and Employability Series One. York: The Higher Education Academy. 